\title{
Modeling Cu Migration in CdTe Solar Cells Under Device-Processing and Long-Term Stability Conditions
}

Conference Paper NREL/CP-520-42580

May 2008

\section{Preprint}

G. Teeter and S. Asher

National Renewable Energy Laboratory

Presented at the 33rd IEEE Photovoltaic Specialists Conference San Diego, California

May 11-16, 2008
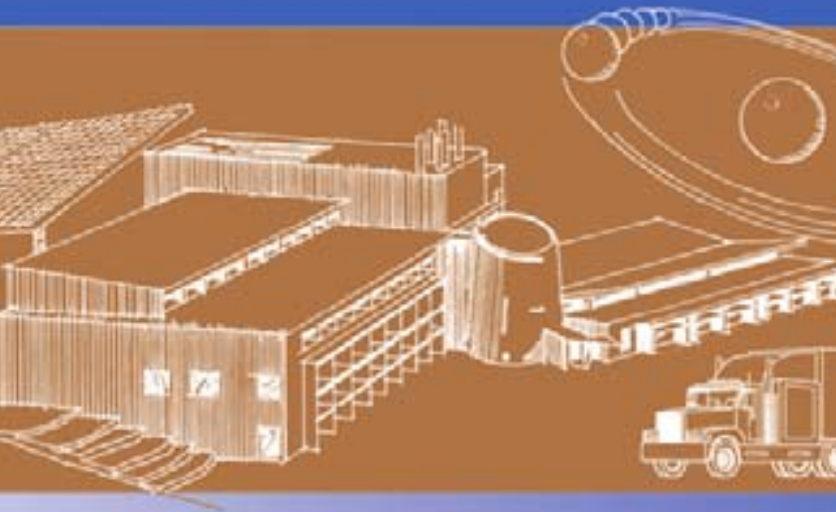


\section{NOTICE}

The submitted manuscript has been offered by an employee of the Midwest Research Institute (MRI), a contractor of the US Government under Contract No. DE-AC36-99G010337. Accordingly, the US Government and MRI retain a nonexclusive royalty-free license to publish or reproduce the published form of this contribution, or allow others to do so, for US Government purposes.

This report was prepared as an account of work sponsored by an agency of the United States government. Neither the United States government nor any agency thereof, nor any of their employees, makes any warranty, express or implied, or assumes any legal liability or responsibility for the accuracy, completeness, or usefulness of any information, apparatus, product, or process disclosed, or represents that its use would not infringe privately owned rights. Reference herein to any specific commercial product, process, or service by trade name, trademark, manufacturer, or otherwise does not necessarily constitute or imply its endorsement, recommendation, or favoring by the United States government or any agency thereof. The views and opinions of authors expressed herein do not necessarily state or reflect those of the United States government or any agency thereof.

Available electronically at http://www.osti.gov/bridge

Available for a processing fee to U.S. Department of Energy and its contractors, in paper, from:

U.S. Department of Energy

Office of Scientific and Technical Information

P.O. Box 62

Oak Ridge, TN 37831-0062

phone: 865.576 .8401

fax: 865.576 .5728

email: mailto:reports@adonis.osti.gov

Available for sale to the public, in paper, from:

U.S. Department of Commerce

National Technical Information Service

5285 Port Royal Road

Springfield, VA 22161

phone: 800.553 .6847

fax: 703.605.6900

email: orders@ntis.fedworld.gov

online ordering: http://www.ntis.gov/ordering.htm 


\title{
MODELING CU MIGRATION IN CdTe SOLAR CELLS UNDER DEVICE-PROCESSING AND LONG-TERM STABILITY CONDITIONS
}

\author{
Glenn Teeter and Sally Asher \\ National Renewable Energy Laboratory (NREL), 1617 Cole Blvd., MS 3218, Golden, CO 80401
}

\begin{abstract}
An impurity migration model for systems with material interfaces is applied to Cu migration in CdTe solar cells. In the model, diffusion fluxes are calculated from the $\mathrm{Cu}$ chemical potential gradient. Inputs to the model include $\mathrm{Cu}$ diffusivities, solubilities, and segregation enthalpies in CdTe, CdS and contact materials. The model yields transient and equilibrium $\mathrm{Cu}$ distributions in CdTe devices during device processing and under field-deployed conditions. Preliminary results for $\mathrm{Cu}$ migration in $\mathrm{CdTe}$ photovoltaic devices using available diffusivity and solubility data from the literature show that $\mathrm{Cu}$ segregates in the CdS, a phenomenon that is commonly observed in devices after back-contact processing and/or stress conditions.
\end{abstract}

\section{INTRODUCTION}

It is well known that $\mathrm{Cu}$ plays an important role in CdTe-based solar cells by helping to form an Ohmic back contact (BC). (See, e.g., references in Ref. [1].) Also, Cu migration in CdTe solar cells has been implicated in device degradation [2-6]. However, the role of $\mathrm{Cu}$ in degradation remains unclear, in part because the kinetics and equilibria of $\mathrm{Cu}$ migration phenomena in $\mathrm{CdTe}$ photovoltaic (PV) devices are not well understood. Cu incorporation in CdTe devices is generally controlled through time-consuming empirical optimization procedures. Similarly, device degradation issues related to Cu migration have typically relied on empirical approaches [7]. The present work provides a simple physical model for $\mathrm{Cu}$ migration in CdTe devices that can be used to understand and potentially optimize $\mathrm{Cu}$ incorporation processes.

\section{IMPURITY MIGRATION MODEL}

A general impurity migration model has been developed recently at the National Renewable Energy Laboratory (NREL) [8]. The model applies to systems with material interfaces (e.g., CdTe/CdS) that lead to discontinuities in the properties that control impurity segregation; diffusivity, solubility, and segregation enthalpy. The impurity migration model derived in Ref. [8] is reviewed here briefly. Consider a system where individual atomic planes perpendicular to the diffusion coordinate $x$ are indexed by subscript $i$. The free energy is calculated by summing the product of particle number and chemical potential over all species and planes:

$$
A=\sum_{i}\left[\left(n_{i} X_{C u}^{i}\right) \mu_{C u}^{i}+\left(n_{i} X_{p}^{i}\right) \mu_{p}^{i}\right\rfloor
$$

Subscript $p$ denotes the local matrix (CdTe, CdS, etc.) in which $\mathrm{Cu}$ is diffusing. Species are labeled by $s=\mathrm{Cu}, p$, and the number of sites per plane is $n_{i}$. The species-s mole fraction in plane $i$ is $X_{s}^{i}$. For simplicity, the idealsolution model is used for $\mu_{C u}^{i}$ and $\mu_{p}^{i}$. Now a chemical potential, $\mu_{\mathrm{Cu}-p}^{i}$, is defined for plane $i$ that accounts for both species, subject to the complementarity condition $X_{C u}^{i}+X_{p}^{i}=1$. Differentiating Eq. (1) with respect to the amount of $\mathrm{Cu}$ in plane $i$ leads to

$$
\mu_{\mathrm{Cu}-p}^{i}=\frac{1}{n_{i}} \frac{\partial A}{\partial X_{\mathrm{Cu}}^{i}}=\Delta H_{\mathrm{Cu}-p}^{i}+k T \ln \frac{X_{\mathrm{Cu}}^{i}}{1-X_{\mathrm{Cu}}^{i}}
$$

Physically, $\Delta H_{\mathrm{Cu}-p}^{i}$ is the energy difference that accompanies the exchange of a matrix atom $p$ with a $\mathrm{Cu}$ atom in plane $i$. The relationship between $\Delta H_{\mathrm{Cu}-p}^{i}$ and the $\mathrm{Cu}$ migration potential is illustrated in Fig. 1, and is summarized by the parameterization

$$
\Delta H_{\mathrm{Cu}-p}^{i}=-\left(E_{D}^{i}+\phi_{\mathrm{Cu}-p}^{i}\right)
$$

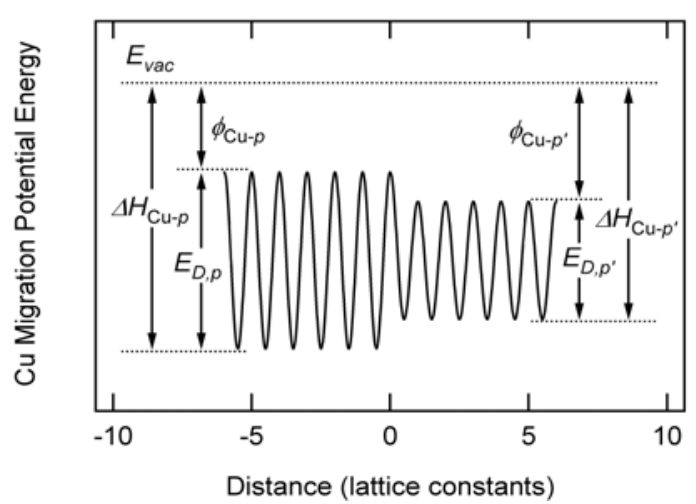

Figure 1. Schematic illustration of the ideal-solution $\mathrm{Cu}$ migration potential near a hypothetical material interface. 
Equation (3) permits the diffusion activation energy, $E_{D}^{i}$, and the local potential energy offset, $\phi_{\mathrm{Cu}-p}^{i}$, to be written as functions of position rather than concentration.

From Fig. 1, the $\mathrm{Cu}$ segregation enthalpy between adjacent layers in the thin-film stack is given by the $\mathrm{Cu}$ migration potential difference across the interface:

$H_{\text {seg }}=\Delta H_{\mathrm{Cu}-p}-\Delta H_{\mathrm{Cu}-p^{\prime}}$.

The layer-i chemical potential, Eq. (2), describes a discretized system of atomic planes. Dropping the $i$ subscripts yields a continuum description. The $\mathrm{Cu}$ flux is given by the standard phenomenological relation:

$J_{\mathrm{Cu}}=-M C_{\mathrm{Cu}} \frac{\partial \mu_{\mathrm{Cu}-p}}{\partial x}$,

where $C_{\mathrm{Cu}}$ is the $\mathrm{Cu}$ concentration. The $\mathrm{Cu}$ flux acts to minimize the free energy with respect to the $\mathrm{Cu}$ concentration profile, and it vanishes at equilibrium. Requiring equal and opposite $\mathrm{Cu}$ and matrix fluxes leads to a generalization of the Einstein relation [9] to non-dilute systems [8], in which mobility $(M)$ is related to diffusivity $(D)$ through

$M=\frac{D}{k T} \frac{C_{p}}{C_{0}}$

$C_{0}$ is the Cu solubility, and $C_{p}$ is the matrix concentration in the Cu-available sites, defined by $C_{0}=C_{\mathrm{Cu}}+C_{p}$. Dropping the unnecessary ' $\mathrm{Cu}$ ' subscripts and assuming an Arrhenius form for $D$ leads to

$J=\frac{C_{p}}{C_{0}}\left(\frac{D C}{k T} \frac{\partial \phi_{\mathrm{Cu}-p}}{\partial x}-C \frac{\partial D}{\partial x}\right)-D\left(\frac{\partial C}{\partial x}-\frac{C}{C_{0}} \frac{\partial C_{0}}{\partial x}\right)$,

and the continuity equation is

$\frac{\partial C}{\partial t}=-\frac{\partial J}{\partial x}$

In any uniform layer, Eq. (7) reduces to $J=-D(\partial C / \partial x)$, Fick's first law of diffusion. Equations (7) and (8) can be solved numerically for the Cu concentration profile in the device for any initial conditions. Required inputs include the $\mathrm{Cu}$ diffusivities, solubilities, and segregation enthalpies for each layer. The device model consists of a BC, CdTe, CdS, and a front contact (FC). A thicker-than-typical CdS layer $(0.5 \mu \mathrm{m})$ is chosen to make this layer more visible in the simulation plots.

\section{SURVEY OF DIFFUSIVITY AND SOLUBILITY DATA}

Solubility and diffusivity data for $\mathrm{Cu}$ in CdTe and CdS are summarized in Table I. Cu solubility and diffusivity data are not available for ZnTe. However, SIMS measurements indicate that high levels of $\mathrm{Cu}$ can be incorporated in sputtered ZnTe:Cu BCs [10-12]. Therefore, for preliminary modeling purposes, a low solubility activation energy was chosen $(0.11 \mathrm{eV})$ for the $B C$, such that $[\mathrm{Cu}]_{\mathrm{BC}}^{\max }>10^{21} \mathrm{~cm}^{-3}$ for $\mathrm{T}>20^{\circ} \mathrm{C}$. Despite the lack of solubility and diffusivity data for $\mathrm{ZnTe}: \mathrm{Cu}$, this allows the $\mathrm{BC}$ layer to act as Cu reservoir in the simulation, and is consistent with SIMS measurements of sputtered ZnTe:Cu $\mathrm{BCs}$ [10-12]. The CdTe:Cu diffusivity parameters were also used for the $\mathrm{BC}$, again due to the lack of data. Arbitrary low values were chosen for the solubility and diffusivity in the FC layer. This leads to low $\mathrm{Cu}$ segregation levels in the FC layer in the simulations, but has little effect on the $\mathrm{Cu}$ profile in other layers of the device.

Table I. Diffusivity and solubility data for $\mathrm{Cu}$ in $\mathrm{CdTe}$ and in CdS. Values used in simulations are in bold type. Singlecrystal based measurements are denoted by SC; measurements from polycrystalline films are indicated by PX. Diffusion mode refers to cases described in the text.

\begin{tabular}{|c|c|c|c|c|}
\hline \multicolumn{5}{|c|}{ CdTe:Cu diffusivity data } \\
\hline$D_{0}\left(\mathrm{~cm}^{2} \mathrm{~s}^{-1}\right)$ & $E_{D}(\mathrm{eV})$ & Ref. & $\begin{array}{c}\text { SC or } \\
\text { PX }\end{array}$ & $\begin{array}{l}\text { Diffusion } \\
\text { mode }\end{array}$ \\
\hline $1.70 \mathrm{E}-06$ & 0.24 & [13] & & \\
\hline 6.65E-05 & 0.57 & [14] & SC & low \\
\hline 7.30E-07 & 0.33 & [15] & & \\
\hline 1.30E-06 & 0.29 & [16] & $P X$ & high \\
\hline 8.20E-08 & 0.64 & [17] & & \\
\hline $3.70 \mathrm{E}-04$ & 0.67 & [18] & & \\
\hline 9.57E-04 & 0.7 & [19] & & \\
\hline \multicolumn{5}{|c|}{ CdTe:Cu solubility data } \\
\hline$C_{0}\left(\mathrm{~cm}^{-3}\right)$ & $E_{a}(\mathrm{eV})$ & Ref. & & \\
\hline $1.56 \mathrm{E}+23$ & 0.55 & [14] & SC & low \\
\hline$\sim 2 E+17$ & $\sim 0$ & [16] & PX & high \\
\hline $3.73 E+24$ & 0.68 & [20] & & \\
\hline \multicolumn{5}{|c|}{ CdS:Cu diffusivity data } \\
\hline$D_{0}\left(\mathrm{~cm}^{2} \mathrm{~s}^{-1}\right)$ & $E_{D}(\mathrm{eV})$ & Ref. & & \\
\hline 1.20E-02 & 1.05 & [21] & SC & \\
\hline $2.10 \mathrm{E}-03$ & 0.96 & [22] & SC & \\
\hline $1.60 \mathrm{E}-03$ & 0.77 & [23] & SC & \\
\hline - & 0.95 & [24] & SC & \\
\hline 6.00E-09 & 0.5 & [25] & $\mathrm{PX}$ & \\
\hline - & 1.0 & [26] & SC & \\
\hline \multicolumn{5}{|c|}{ CdS:Cu solubility data } \\
\hline$C_{0}\left(\mathrm{~cm}^{-3}\right)$ & $E_{a}(\mathrm{eV})$ & Ref. & & \\
\hline $8.00 \mathrm{E}+21$ & 0.27 & [25] & $P X$ & \\
\hline $6.60 \mathrm{E}+22$ & 0.505 & [22] & SC & \\
\hline
\end{tabular}

It has been pointed out that there appear to be two mechanisms for $\mathrm{Cu}$ diffusion in $\mathrm{CdTe}$ : via $\mathrm{Cu}$ atoms on $\mathrm{Cd}$ lattice sites $\left(\mathrm{Cu}_{\mathrm{Cd}}\right)$, and via interstitial $\mathrm{Cu}$ ions $\left(\mathrm{Cu}_{i}^{+}\right)[16$, 18]. Other workers have suggested that the dominant diffusion mechanism is a neutral $\mathrm{Cu}$ interstitial $\mathrm{Cd}$ vacancy $\left(\mathrm{Cu}_{i}-\mathrm{V}_{\mathrm{Cd}}\right)$ complex $[14,27]$. Single-crystal measurements indicate that the $\mathrm{Cu}_{\mathrm{Cd}}$ (or $\mathrm{Cu}_{\mathrm{i}}-\mathrm{V}_{\mathrm{Cd}}$ ) solubility is significantly higher than that of $\mathrm{Cu}_{i}^{+}$, and that $\mathrm{Cu}_{\mathrm{Cd}}$ has the lower diffusivity $[14,18]$. The $\mathrm{Cu}_{i}^{+}$solubility is apparently nearly 
constant with temperature [14]. Data for both mechanisms are used in this study for comparative purposes: the diffusivity from Ref. [14] is the 'low-diffusivity' case, and that from Ref. [16] is 'high-diffusivity' case. The corresponding solubilities are also used.

It is very likely that grain-boundaries in polycrystalline films significantly enhance the diffusivity and solubility of $\mathrm{Cu}$ compared to in single-crystal samples. Currently, there is not sufficient data available in the literature to definitively quantify these effects in CdTe PV devices. Nevertheless, it should be noted that the high-diffusivity case referred to in this work is based on measurements of polycrystalline films, whereas the low-diffusivity case is based on single-crystal measurements. Therefore, the high-diffusivity case is probably more relevant to $\mathrm{Cu}$ migration in thin-film based CdTe solar cells. For CdS, there is only one set of diffusivity and solubility measurements available for polycrystalline thin films [25]. Therefore, solubility and diffusivity data for the simulations were chosen from this study.

The segregation enthalpy, Eq. (4), depends on the diffusivities and local potential-energy offsets for $\mathrm{Cu}$ in each material layer, and therefore must be measured independently for each pseudo-binary diffusion couple. These data are not presently available, so the simulations assume that the corresponding term in Eq. (7) is zero.

\section{CU MIGRATION SIMULATION RESULTS}

For all simulations, the initial $\mathrm{Cu}$ concentration was set to $10^{21} \mathrm{~cm}^{-3}$ in the BC layer, and zero elsewhere. For the device-processing simulation, the temperature was ramped from room temperature to the indicated temperatures at $20^{\circ} \mathrm{C} \mathrm{min}{ }^{-1}$, held at temperature for a time equal to the duration of the temperature ramp, then ramped back to room temperature. These preliminary simulation results are shown in Figs. 2 and 3.

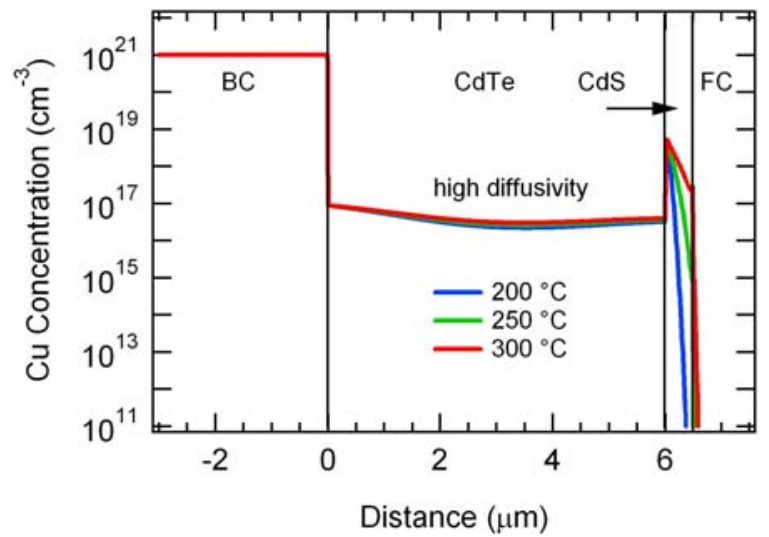

Figure 2. Device-processing simulation of $\mathrm{Cu}$ migration in CdTe PV device for the high-diffusivity case.

The extent of $\mathrm{Cu}$ segregation increases with annealing temperature, due to increased CdTe:Cu diffusivity and $\mathrm{CdS}: \mathrm{Cu}$ solubility. There are also $\mathrm{Cu}-$ depleted regions near the $B C$ interface for the lowdiffusivity case. This results from $\mathrm{Cu}$ re-segregation to the $\mathrm{BC}$ during the ramp back to room temperature, caused by the corresponding decrease of $\mathrm{Cu}$ solubility in CdTe. In spite of this phenomenon, the simulations show that a metastable $\mathrm{Cu}$ concentration in excess of the Cu solubility can be established during $\mathrm{BC}$ processing: the $\mathrm{Cu}_{\mathrm{Cd}}$ solubility is $5 \times 10^{13} \mathrm{~cm}^{-3}$ at $20^{\circ} \mathrm{C}$ [14].

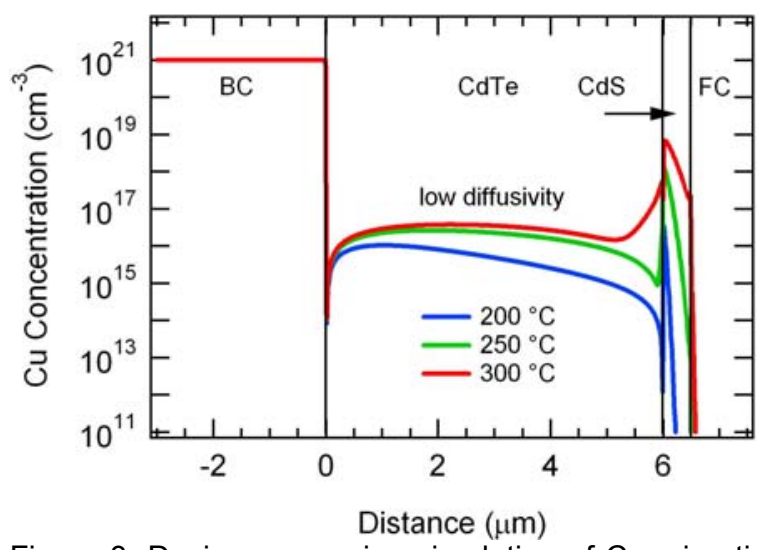

Figure 3. Device-processing simulation of $\mathrm{Cu}$ migration in CdTe PV device for the low-diffusivity case.

Figures 4 and 5 show the results from the preliminary long-term stability simulations, for $\mathrm{T}=65^{\circ} \mathrm{C}$.

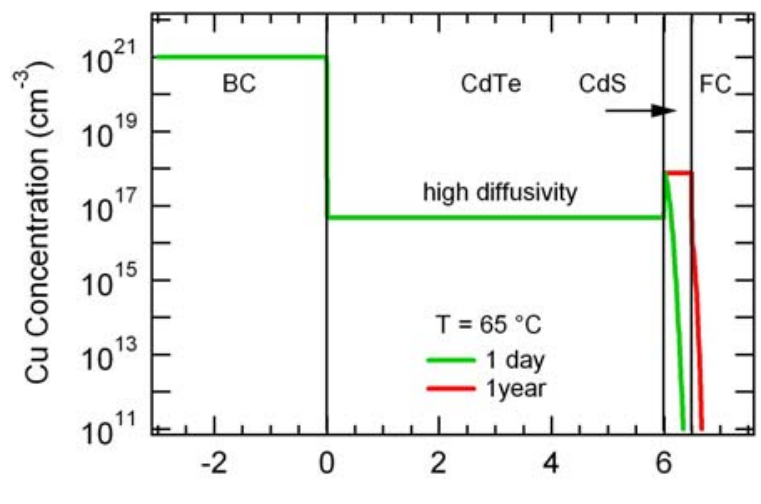

Distance $(\mu \mathrm{m})$

Figure 4. Long-term stability simulation of $\mathrm{Cu}$ migration in CdTe PV device for the high-diffusivity case.

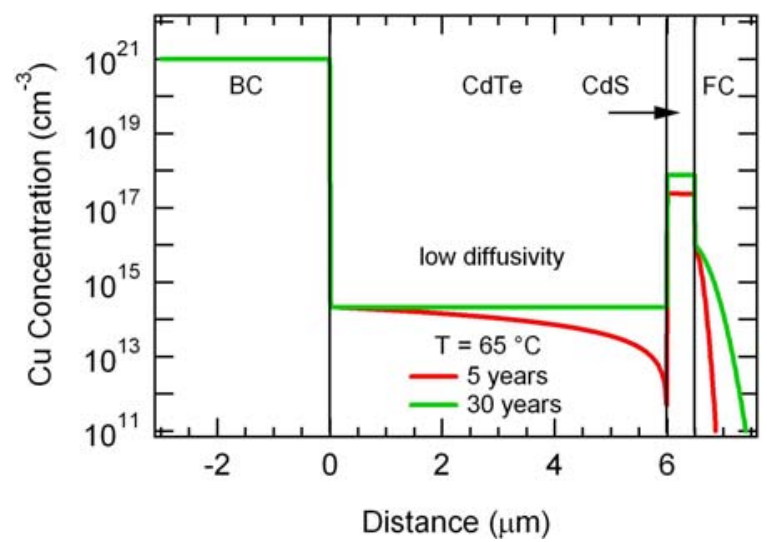

Figure 5. Long-term stability simulation of $\mathrm{Cu}$ migration in CdTe PV device for the low-diffusivity case.

For these results, it is noteworthy that high levels of $\mathrm{Cu}$ in the CdS layer are established relatively quickly. For 
the high-diffusivity case, the detailed temporal evolution of the $\mathrm{Cu}$ profile (not shown for lack of space) show that equilibrium in the CdTe and CdS layers is established within about 20 weeks at $65^{\circ} \mathrm{C}$. Similarly, for the lowdiffusivity case, a large $\mathrm{Cu}$ concentration develops in the CdS after about 5 years, and equilibrium is established in 10-15 years.

As was observed for the CdTe layer, the Cu levels in the CdS layer in the device-processing simulation again exceed the solubility (cf. Figs. 2 and 4 and Figs. 3 and 5). Therefore, in actual devices, it is possible under some conditions that a gradual decrease in Cu concentration in the CdS layer could be observed following $\mathrm{BC}$ processing.

$\mathrm{Cu}$ accumulation in the CdS layer is observed in all of the simulations, consistent with observations of real devices [4]. It is apparent from the model that both enhanced solubility and decreased diffusivity of $\mathrm{Cu}$ in $\mathrm{CdS}$ compared to CdTe contribute to this phenomenon. Without more systematic diffusion, solubility and migration measurements on thin-film materials (and diffusion couples) used in CdTe devices, it will be difficult to address this issue definitively. Nevertheless, in the simulations reported here it appears that solubility is the primary driving force for $\mathrm{Cu}$ accumulation in the CdS layer. This observation is consistent with the interpretation of enhanced grain-boundary segregation in CdS films, which typically have smaller grains and therefore more grainboundary surface area per unit volume than CdTe films, is responsible for $\mathrm{Cu}$ accumulation in this layer.

For comparison to the simulation results, a SIMS depth profile of $\mathrm{Cu}$ obtained from a CdTe solar cell is shown in Fig. 6. The cell was fabricated on Tec 15 glass with vapor-transport-deposited $\mathrm{CdTe} / \mathrm{CdS}$ absorber and vapor- $\mathrm{CdCl}_{2}$ processed. The back contact was a sputterdeposited bi-layer of ZnTe:Cu followed by Ti, deposited at temperatures of $\sim 325^{\circ} \mathrm{C}$ and $\sim 185^{\circ} \mathrm{C}$, respectively. The $\mathrm{Ti}$ was removed prior to SIMS analysis.

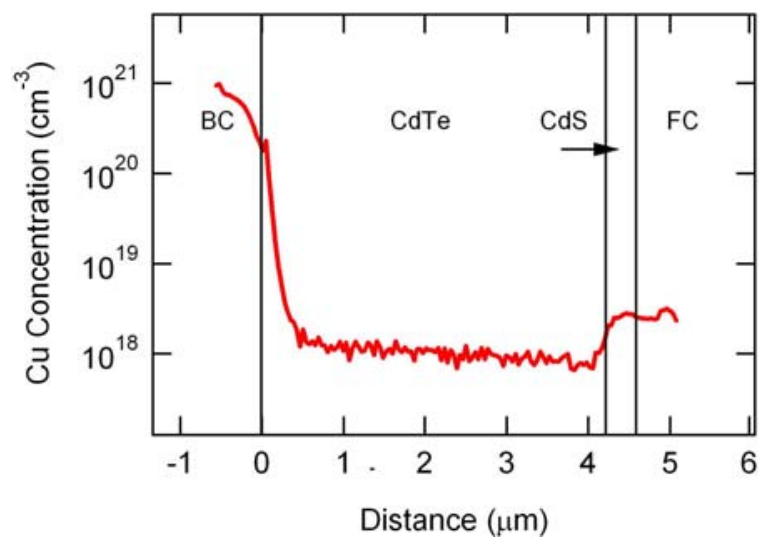

Figure 6. Typical SIMS profile of a ZnTe:Cu backcontacted device after back-contact processing.

The $\mathrm{Cu}$ distribution measured by SIMS is similar to the simulated high-diffusivity case. The $\mathrm{Cu}$ concentration in the simulation is roughly one order of magnitude lower, and the concentration in the CdS is somewhat higher, than in the SIMS profile, indicating that the parameters used in the model are not quite correct for these particular thinfilms. For example, the effective solubilities in these layers are highly dependent on grain size. Additionally, the kinetic and thermodynamic parameters controlling diffusivity and segregation in these thin-film layers might be influenced by the particular growth parameters, or other processing steps such as the $\mathrm{CdCl}_{2}$ treatment. It is also important to note that artifacts in SIMS data, such as sputter-induced roughening or other morphological effects, are not accounted for in the migration model. These types of artifacts in SIMS data tend to broaden profiled, whereas the model assumes abrupt interfaces. Nevertheless, there is sufficient qualitative (or semi-quantitative) agreement between the simulations and SIMS profiles of actual devices to suggest that the segregation model captures all relevant thermodynamic driving forces for $\mathrm{Cu}$ migration. Further experimental data and simulations will allow the model and material parameters to be refined.

\section{SUMMARY AND CONCLUSIONS}

An impurity migration model has been applied to $\mathrm{Cu}$ in CdTe PV devices using available diffusivity and solubility data. The device-processing simulations agree qualitatively with observations of $\mathrm{Cu}$ segregation in the CdS layer [4, 10-12], an effect attributed primarily to enhanced grain-boundary segregation in fine-grained CdS films. For the diffusivity measured in single-crystal CdTe [14], long-term stability simulations show that $\mathrm{Cu}$ segregation to the CdS layer equilibrates within about 15 years. The much faster diffusivity measured in polycrystalline CdTe leads to a $\mathrm{Cu}$ profile in the device equilibrates within weeks. These timescales are clearly relevant to discussions of device degradation in the field. However, more experiments are needed to definitively identify the dominant $\mathrm{Cu}$ diffusion mechanism in CdTe thin-films used for PV applications.

In order to verify and refine the $\mathrm{Cu}$ migration model, it would be extremely useful to measure (or re-measure) $\mathrm{Cu}$ diffusivities, solubilities, and segregation enthalpies for relevant thin-film PV materials. Grain boundaries are known to affect both the diffusivity and solubility of $\mathrm{Cu}$ in CdTe [2], and similar behavior is expected in CdS, ZnTe, etc. Therefore these properties must be measured in actual thin-film PV materials.

\section{ACKNOWLEDGMENTS}

This work was supported by the U.S. Department of Energy under Contract No. DE-AC36-99G010337 with the National Renewable Energy Laboratory.

\section{REFERENCES}

[1] G. Teeter, "X-ray and ultraviolet photoelectron spectroscopy measurements of Cu-doped CdTe(111)-B: Observation of temperature-reversible CuxTe precipitation and effect on ionization potential," Journal of Applied Physics, vol. 102, pp. 034504, 2007.

[2] H. C. Chou, A. Rohatgi, N. M. Jokerst, E. W. Thomas, and S. Kamra, "Copper migration in CdTe heterojunction solar cells," Journal of Electronic Materials, vol. 25, pp. 1093-1098, 1996. 
[3] D. Grecu and A. D. Compaan, "Photoluminescence study of Cu diffusion and electromigration in CdTe," Applied Physics Letters, vol. 75, pp. 361-363, 1999.

[4] S. E. Asher, F. S. Hasoon, T. A. Gessert, M. R. Young, P. Sheldon, J. Hiltner, and J. Sites, "Determination of $\mathrm{Cu}$ in CdTe/CdS devices before and after accelerated stress testing," Conference Record of the Twenty-Eighth IEEE Photovoltaic Specialists Conference - 2000 (Cat. No.00CH37036), pp. 479-482, 2000.

[5] T. J. Berniard, D. S. Albin, B. To, J. W. Pankow, M. Young, and S. E. Asher, "Effects of $\mathrm{Cu}$ at the device junction on the properties of CdTe/CdS photovoltaic cells," Journal of Vacuum Science \& Technology B, vol. 22, pp. 2423-2428, 2004.

[6] C. R. Corwine, A. O. Pudov, M. Gloeckler, S. H. Demtsu, and J. R. Sites, "Copper inclusion and migration from the back contact in CdTe solar cells," Solar Energy Materials and Solar Cells, vol. 82, pp. 481-489, 2004.

[7] D. S. Albin, S. H. Demtsu, and T. J. McMahon, "Film thickness and chemical processing effects on the stability of cadmium telluride solar cells," Thin Solid Films, vol. 515, pp. 2659-2668, 2006.

[8] G. Teeter, to be published.

[9] A. Einstein, Ann. Phys., pp. 549, 1905.

[10] C. Narayanswamy, T. A. Gessert, and S. E. Asher, "Analysis of $\mathrm{Cu}$ diffusion in $\mathrm{ZnTe}$-based contacts for thinfilm CdS/CdTe solar cells," AIP Conference Proceedings, pp. 248-253, 1999.

[11] T. A. Gessert, C. L. Perkins, S. E. Asher, A. Duda, and M. R. Young, "Study of ZnTe:Cu/metal interfaces in $\mathrm{CdS} / \mathrm{CdTe}$ photovoltaic solar cells," Critical Interfacial Issues in Thin-Film Optoelectronic and Energy Conversion Devices Symposium (Mater. Res. Soc. Symposium Proceedings Vol.796), pp. 79-84, 2004.

[12] T. A. Gessert, S. Smith, T. Moriatry, M. Young, S. Asher, S. Johnston, A. Duda, C. DeHart, and A. L. Fahrenbruch, "Evolution of CdS/CdTe device performance during Cu diffusion," Conference Record of the Thirty-First IEEE Photovoltaic Specialist Conference (IEEE Cat. No. 05CH37608), pp. 291-294, 2005.

[13] B. O. Wartlick, C. Blanchard, and J. F. Barbot, "Study of silver and copper diffusion in p-type Hg/sub 0.3/Cd sub 0.7/Te and CdTe by capacitance measurements," Materials Science \& Engineering B (Solid-State Materials for Advanced Technology), vol. B71, pp. 254-257, 2000.

[14] E. D. Jones, N. M. Stewart, and J. B. Mullin, "The diffusion of copper in cadmium telluride," Journal of Crystal Growth, vol. 117, pp. 244-248, 1992.
[15] T. D. Dzhafarov, S. S. Yesilkaya, N. Y. Canli, and M. Caliskan, "Diffusion and influence of $\mathrm{Cu}$ on properties of CdTe thin films and CdTe/CdS cells," Solar Energy Materials and Solar Cells, vol. 85, pp. 371-383, 2005.

[16] R. A. Enzenroth, K. L. Barth, and W. S. Sampath, "Transient ion drift measurements of polycrystalline CdTe PV devices," Conference Record of the 2006 IEEE 4th World Conference on Photovoltaic Energy Conversion (IEEE Cat. No. 06CH37747), pp. 4 -4, 2006.

[17] H. Mann, G. Linker, and O. Meyer, "Diffusion processes at the $\mathrm{Cu}-\mathrm{CdTe}$ interface for evaporated and chemically plated Cu layers," Solid State Communications, vol. 11, pp. 475-479, 1972.

[18] H. H. Woodbury and M. Aven, "Some Diffusion and Solubility Measurments of $\mathrm{Cu}$ in CdTe," Journal of Applied Physics, vol. 39, pp. 5485-5488, 1968.

[19] O. E. Panchuk, V. I. Grytsiv, and D. P. Belotskii, "Diffusion of Cu in CdTe," Inorganic Materials, vol. 11, pp. 1510-1512, 1975.

[20] A. V. Vishnyakov, V. N. Zubkovskaya, and T. V. Kukleva, "Solubility of copper in cadmium telluride," Inorganic Materials, vol. 25, pp. 502-505, 1989.

[21] J. L. Sullivan, "An ultrasonic investigation of the diffusion of noble metals in CdS," Journal of Physics $D$ (Applied Physics), vol. 6, pp. 552-559, 1973.

[22] J. L. Sullivan, "Diffusion and Solubility of $\mathrm{Cu}$ in CdS Single Crystals," Physical Review, vol. 184, pp. 796-805, 1969.

[23] R. L. Clarke, "Diffusion of Copper Cadmium Sulfide Crystals," Journal of Applied Physics, vol. 30, pp. 957-960, 1959.

[24] L. V. Borkovskaya, B. R. Dzhumaev, L. Y. Khomenkova, N. E. Korsunskaya, I. V. Markevich, and M. K. Sheinkman, "About the nature of diffusion anisotropy in CdS crystals," Semiconductor Physics Quantum Electronics \& Optoelectronics, vol. 3, pp. 282-286, 2000.

[25] E. B. Kaganovich, I. K. Ostrovskaya, Y. S. Pilipyuk, and E. M. Pochtar, "Diffusion and solubility of copper in photoconductive CdS films precipitated from aqueous solution," Inorganic Materials, vol. 24, pp. 1236-1238, 1988.

[26] L. V. Borkovska, L. Y. Khomenkova, N. E. Korsunska, I. V. Markevich, and M. K. Sheinkman, "Some peculiarities of impurity diffusion in CdS crystals," Physica Status Solidi $B$, vol. 229, pp. 269-273, 2002.

[27] D. Shaw, "Diffusion mechanisms in II-VI materials," Journal of Crystal Growth, vol. 86, pp. 778-796, 1988. 


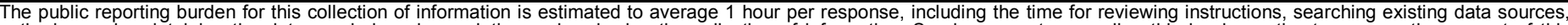

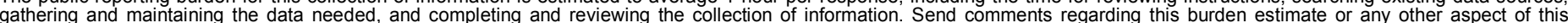

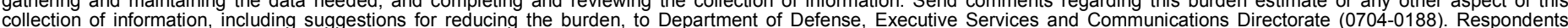

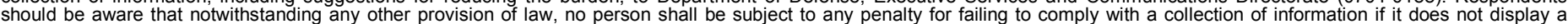

should be aware that notwithstanding

PLEASE DO NOT RETURN YOUR FORM TO THE ABOVE ORGANIZATION.

\section{REPORT DATE (DD-MM-YYYY) May 2008}

\section{TITLE AND SUBTITLE}

Modeling Cu Migration in CdTe Solar Cells Under Device-

Processing and Long-Term Stability Conditions: Preprint
3. DATES COVERED (From - To)

11-16 May 2008

5a. CONTRACT NUMBER

DE-AC36-99-G010337

5b. GRANT NUMBER

5c. PROGRAM ELEMENT NUMBER

5d. PROJECT NUMBER

NREL/CP-520-42580

5e. TASK NUMBER

PVA73301

5f. WORK UNIT NUMBER
7. PERFORMING ORGANIZATION NAME(S) AND ADDRESS(ES)

National Renewable Energy Laboratory

1617 Cole Blvd.

Golden, CO 80401-3393
8. PERFORMING ORGANIZATION REPORT NUMBER

NREL/CP-520-42580

9. SPONSORING/MONITORING AGENCY NAME(S) AND ADDRESS(ES)

10. SPONSOR/MONITOR'S ACRONYM(S) NREL

11. SPONSORING/MONITORING AGENCY REPORT NUMBER

12. DISTRIBUTION AVAILABILITY STATEMENT

National Technical Information Service

U.S. Department of Commerce

5285 Port Royal Road

Springfield, VA 22161

13. SUPPLEMENTARY NOTES

14. ABSTRACT (Maximum 200 Words)

An impurity migration model for systems with material interfaces is applied to Cu migration in CdTe solar cells. In the model, diffusion fluxes are calculated from the $\mathrm{Cu}$ chemical potential gradient. Inputs to the model include $\mathrm{Cu}$ diffusivities, solubilities, and segregation enthalpies in CdTe, CdS and contact materials. The model yields transient and equilibrium $\mathrm{Cu}$ distributions in CdTe devices during device processing and under field-deployed conditions. Preliminary results for $\mathrm{Cu}$ migration in CdTe photovoltaic devices using available diffusivity and solubility data from the literature show that $\mathrm{Cu}$ segregates in the $\mathrm{CdS}$, a phenomenon that is commonly observed in devices after backcontact processing and/or stress conditions.

15. SUBJECT TERMS

PV; migration simulation; grain boundary; diffusion flux; device processing; solar cells; thin film;

\begin{tabular}{|c|c|c|}
\hline 16. SECURITY & CLASSIFICATI & N OF: \\
\hline $\begin{array}{l}\text { a. REPORT } \\
\text { Unclassified }\end{array}$ & $\begin{array}{l}\text { b. ABSTRACT } \\
\text { Unclassified }\end{array}$ & $\begin{array}{l}\text { c. THIS PAGE } \\
\text { Unclassified }\end{array}$ \\
\hline
\end{tabular}

\begin{tabular}{|c|c|}
\hline $\begin{array}{l}\text { 17. LIMITATION } \\
\text { OF ABSTRACT }\end{array}$ & \multirow{2}{*}{$\begin{array}{l}\text { 18. NUMBER } \\
\text { OF PAGES }\end{array}$} \\
\hline UL & \\
\hline
\end{tabular}

19a. NAME OF RESPONSIBLE PERSON

19b. TELEPHONE NUMBER (Include area code) 